\title{
Evaluation of magnocellular pathway abnormalities in schizophrenia: a frequency doubling technology study and clinical implications
}

\author{
Avaliação das alterações da via magnocelular na esquizofrenia usando FDT e suas implicações clínicas
}

Fabiana Benites Vaz de Lima ${ }^{1,2}$, Carolina Pelegrini Barbosa Gracitelli ${ }^{3}$, Augusto Paranhos Junior ${ }^{3}$, Rodrigo Affonseca Bressan ${ }^{1,2}$

\begin{abstract}
Background:Visual processing deficits have been reported for patients with schizophrenia. Previous studies demonstrated differences in early-stage processing of schizophrenics, although the nature, extent, and localization of the disturbance are unknown. The magnocellular and parvocellular visual pathways are associated with transient and sustained channels, but their respective contributions to schizophrenia-related visual deficits remains controversial.

Purpose: The aim of this study was to evaluate magnocellular dysfunction in schizophrenia using frequency doubling technology.

Methods: Thirty-one patients with schizophrenia and 34 healthy volunteers were examined. Frequency doubling technology testing was performed in one session consisting of a 15-minute screening strategy followed by the C-20 program for frequency doubling technology

Results: Schizophrenic patients showed lower global mean sensitivity $(30,97 \pm$ $2,25 \mathrm{~dB})$ compared with controls $(32,17 \pm 3,08 \mathrm{~dB}), \mathrm{p}<0.009$. Although there was no difference in the delta sensitivity of hemispheres, there was a difference in sensitivity analysis of the fibers crossing the optic chiasm, with lower mean sensitivity in the patient group $(28,80 \mathrm{~dB})$ versus controls $(30,66 \mathrm{~dB})$. The difference was higher in fibers that do not cross the optic chiasm, with lower mean sensitivity in patients $(27,61 \mathrm{~dB})$ versus controls $(30,26 \mathrm{~dB}), \mathrm{p}<0.005$.

Conclusions: Our results suggest that there are differences between global sensitivity and fiber sensitivity measured by frequency doubling technology. The different sensitivity of fibers that do not cross the optic chiasm is consistent with most current etiological hypotheses for schizophrenia. The decreased sensitivity responses in the optic radiations may significantly contribute to research assessing early-stage visual processing deficits for patients with schizophrenia.
\end{abstract}

Keywords: Schizophrenia; Visual perception; Visual pathways; Basal nucleus of Meynert

\section{RESUMO}

Histórico: Déficits de processamento visual foram relatados em pacientes com esquizofrenia. Estudos anteriores demonstraram diferenças no estágio inicial de processamento de esquizofrênicos, embora a natureza, extensão elocalização do distúrbio são desconhecidas. As vias magnocelulares e parvocelular visuais são associados com canais transitórios esustentado, mas suas respectivas contribuições para a esquizofrenia relacionados com déficits visuais permanece controverso.

Objetivo: Avaliar a disfunção magnocelular na esquizofrenia usando a tecnologia de frequência dupla.

Métodos: Trinta e um pacientes com esquizofrenia e 34 voluntários saudáveis foram examinados. Tecnologia de frequência dupla foi realizada em uma sessão, consistindo de uma estratégia de rastreio de 15 minutos, seguido do programa de C-20 para tecnologia de frequência dupla.

Resultados: Os pacientes esquizofrênicos apresentaram sensibilidade média inferior global (30,97 $\pm 2,25 d B)$, em comparação com os controles $(32,17 \pm 3,08 d B), p<0,009$. Embora não tenha ocorrido diferença na sensibilidade do delta de hemisférios, houve uma diferenç na análise de sensibilidade das fibras que atravessam a quiasma, com menor sensibilidade média no grupo de pacientes $(28,80 \mathrm{~dB})$ versus controlos $(30,66$ dB). A diferença foi maior em fibras que não cruzam o quiasma óptico, com menor sensibilidade média em pacientes $(27,61 \mathrm{~dB})$ versus controles $(30,26 \mathrm{~dB}), p<0,005$.

Conclusões: Nossos resultados sugerem que hádiferenças entre a sensibilidade global e sensibilidade da fibra medida pela tecnologia de frequência dupla. A sensibilidade diferente de fibras que não cruzam o quiasma óptico é compativel com a maioria das atuais hipóteses etiológicas para a esquizofrenia. As respostas diminuição da sensibilidade nas radiações ópticas podem contribuir significativamente para pesquisar a avaliação em estágio inicial déficits de processamento visual em pacientes com esquizofrenia.

Descritores: Esquizofrenia; Percepção visual; Vias visuais; Núcleo basal de Meynert

\section{INTRODUCTION}

Schizophrenia is a severe mental disorder and considered a public health issue. The cost of schizophrenia includes lost income, public aid, and drug and psychosocial treatments ${ }^{(1)}$. Despite all the treatments currently available, patients with schizophrenia still suffer from a combination of symptoms, such as delusions, hallucinations, and social withdrawal|(1,2).

Among many hypotheses for schizophrenia's etiology, the neurodevelopmental model is one of the most important ${ }^{(3)}$. The visual pathway may be a good marker for central nervous system development. The recent advances in understanding the neural networks involved in visual perception allow a better comprehension of the pathophysiology of neurodevelopmental and psychiatric disorders ${ }^{(4,5)}$.

Schizophrenia patients' exhibit deficits in several neurophysiologic measures of information processing that have been proposed as candidate endophenotypes ${ }^{(6)}$. A number of studies that provide evidence to support the hypothesis that the deficit in the magnocellular pathway is a trait of vulnerability to schizophrenia ${ }^{(7,8)}$.

Deficits in visual performance of patients with schizophrenia have been described for many years, but this may be due to several factors, from peripheral sensory abnormalities (slow neuronal transmission) to losses in higher cortical functioning ${ }^{(6,9-11)}$. Furthermore, fai-
Funding: No specific financial support was available for this study.

Disclosure of potential conflicts of interest: F.B.V.de Lima, is employee of AstraZeneca; C.P.B.Gracitelli, None; A.Paranhos Jr, None; R.A. Bressan has received grant/ research support from Janssen-Cilag, AstraZeneca, Eli Lilly, and Novartis.

Correspondence address: Carolina Pelegrini Barbosa. Rua Botucatu, 821 - São Paulo (SP) 04023-062 - Brazil - E-mail: carolepm@gmail.com 
lures in this system cause a lack of information to the visual cortex, and these result in clinical symptoms for patients ${ }^{(12)}$. The most frequent clinical symptoms include selective attention in sustained attention and disturbance of short-term visual memory ${ }^{(13-15)}$.

The subcortical projections of the retina to the cerebral cortex are formed mainly by two pathways (magnocellular and parvocellular) related to subdivisions of the lateral geniculate body with the same name. These pathways are of great importance because they contain approximately $90 \%$ of axons leaving the retina and maintain their anatomical segregation of projections through the lateral geniculate body in the V1 layer 4C of the striate cortex ${ }^{(14)}$.

Psychophysical studies of specific visual functions have been used to measure visual performance and understand retinal ganglion cell functioning. Some studies suggested that the visual deficit is in the magnocellular pathway, or the transient channels. Other studies claim that the visual deficit is in the parvocellular pathway or the sustained channels, or the interaction of the abnormal magnocellular and parvocellular channels ${ }^{(16-18)}$. Although many studies have established that there are differences in early visual processing in schizophrenia patients, the nature, extent, and location of this abnormality remain uncertain ${ }^{(19,20)}$

The magnocellular pathway is formed by large neurons that project the visual stimuli to the dorsal visual stream, and is primarily involved with the motion and location of the stimulus (the "where" system) ${ }^{(20)}$. The parvocellular pathway is composed of smaller neurons, with slower neuronal driving, which project to the ventral visual stream and is primarily responsible for recognition of the object (the "what" system). Despite the preference of the dorsal and ventral magnocellular and parvocellular neurons, visual information also crosses between hemispheres ${ }^{(20)}$

The physiological responses of ganglion cells in the magnocellular and parvocellular pathways are similar in some domains and completely different in others. The major difference is the response to color sensitivity. Parvocellular neurons respond to the stimulus of alternation green/red or blue/yellow, and show some response despite the change of color luminescence. In the case of magnocellular neurons, there is no response to alternation of colors when the luminescence is balanced ${ }^{(21)}$.

Another difference in physiological responses between parvocellular and magnocellular neurons is present in contrast sensitivity. The response to contrast sensitivity is much greater in magnocellular cells, which respond to stimuli with contrast less than $2 \%$, while the parvocellular cells rarely respond to a contrast less than $10 \%{ }^{(20,21)} \cdot$ In other dimensions of visual stimuli, including spatial response, temporal, and luminescence contrast, neurons via the parvocellular and magnocellular pathways have different responses; however, there is overlap in the rates of sensitivity ${ }^{(20)}$.

The aim of this study was to evaluate the initial visual processing (perception of the stimulus by ganglion cells) using frequency doubling technology (FDT) in patients with schizophrenia compared with healthy controls, and evaluate the relationship between the deficit in visual processing with socio-demographic factors and clinical factors associated with chronicity, such as negative symptoms, duration of the disease, and antipsychotic drug use.

\section{METHODS}

\section{Participants}

We recruited patients with diagnoses of schizophrenia from the Schizophrenia Program at the Federal University of São Paulo. The control group was recruited from the hospital staff community and students at the same university. The participation of individuals in the study was voluntary and all signed the Term of Free and Informed Consent, previously approved by the Ethics Committee of the Federal University of São Paulo.
Inclusion criteria for patients included: 1) fulfill the diagnosis of schizophrenia made through the application of the Structured Clinical Interview for DSM-IV (SCID) by a trained psychiatrist; 2) good vision (visual acuity greater 20/60) tested by Snellen chart; 3 ) intraocular pressure lower than $20 \mathrm{mmHg}$ measured by Perkins tonometry; and 4) normal biomicroscopic examination and normal optic nerve (excavation/disc equal to or less than 0.6 SD) assessed by a ophthalmologist ${ }^{(22)}$.

The exclusion criteria for patients included: 1) presence of a history of abuse on alcohol or drugs; 2) presence of any neurological disease that could affect performance on the test; and 3) diseases affecting the visual field.

The inclusion criteria for controls: 1) mental status assessment by Self-Report Questionnaire (SRQ-20) with cut-off less than or equal to 7 positive answers; and 2) the same ophthalmologic inclusion criteria applied for the schizophrenic patients. A family history of glaucoma was allowed (23).

The exclusion criteria for controls: 1) presence of psychiatric illness; 2) substance abuse; 3) diseases affecting the visual field; and 4) presence of a systemic disease that can potentially affect the visual system.

\section{Psychiatric assessment}

The presence of positive and negative symptoms was assessed by the Positive and Negative Syndromes Scale (PANSS) ${ }^{(24)}$. Schizophrenic patients were classified into negative, positive, or mixed according to the parameters of Andreasen and Olsen ${ }^{(24)}$.

Patients were evaluated and classified according to antipsychotic medication in use. The type of antipsychotics included first and second generation antipsychotics or a combination of both. The dose of chlorpromazine equivalents for each antipsychotic used at the time of examinations was calculated.

Control participants were evaluated with the SRQ-20 and were excluded from the study if their scores were higher than 7.

\section{Ophthalmologic evaluation}

Participants were submitted to an ophthalmological examination, which included: measurement of visual acuity, refraction, slit-lamp biomicroscopy of the anterior chamber, measurement of intraocular pressure, and fundus examination.

Patients and volunteers were tested: light stimuli were presented and participants responded according to their ability to detect the stimuli. Participants first received the necessary instructions for performing the examination. Next, participants began a 15-minute strategy of screening, where participants learned to recognize the stimuli and adapt to the test. The stimuli were presented on the computer screen and the participants were required to press a button when they saw the gray square. Testing was conducted in a darkened room.

FDT measures the contrast needed for detection of the stimulus. Each grating target is a square extending approximately $10^{\circ}$ in diameter. Targets are presented in one of 18 areas located $20^{\circ}$ radius of the visual field temporally and $30^{\circ}$ nasally ${ }^{(25)}$. FDT was performed with the $\mathrm{C}-20$ program, which is the proper evaluation of the magnocellular cells, using a sinusoidal pattern of light stimuli and temporal frequency of $50 \mathrm{~Hz}^{(25,26)}$. FDT was measured with the frequency doubling visual field instrument (Carl Zeiss Meditec, Dublin, CA).

\section{Statistical analysis}

The analyses of FDT global retinal sensitivity were performed comparing the mean-deviation (MD) of patients versus controls using unpaired $t$ test. The right hemisphere analysis included the mean sensitivity of the right nasal and left temporal hemifields. The left hemisphere analysis included the mean sensitivity of the right temporal and left nasal hemifields. We also performed a retinal sensitivity analysis between the fibers crossing the optic chiasm and those that do not cross. 
Statistical analyses were performed using the SPSS statistical package, version 17.0, (SPSS Inc., Chicago, USA). Generalized estimated equation (GEE) was performed to evaluate differences among the groups and to correct the dependency between the eyes, according to hemispheres, and fibers that cross or do not cross the optic chiasm $^{(27)}$.

As a secondary analysis, MD values were used as the dependent variable in the logistic regression model with the following independent variables: age, gender, disease duration, antipsychotic treatment, positive and negative symptoms, and education level.

\section{RESULTS}

We evaluated 31 outpatients (24 male/7 female) diagnosed with schizophrenia using the SCID criteria of the DSM-IVR, and 34 health controls (8 male/26 female). The participants' socio-demographic characteristics are described in table 1. The ophthalmologic evaluation revealed that both groups had visual acuity, as tested by Snellen chart, that was higher than 20/60 (Table1). Intraocular pressure was normal (less than $20 \mathrm{mmHg}$ ) for both groups, although there was a significant difference between groups of less than $2 \mathrm{mmHg}$. This difference is not clinically relevant and cannot affect the FDT results.

In the sample studied, only two patients were employed at the time of evaluation; the remaining 32 (94\%) were retired or receiving sickness benefit.

All patients were using antipsychotic drugs or other psychotropic agents for at least 6 months. The patients were also assessed by the PANSS scale and classified according to symptomatic group: ten were classified as negative type, ten were positive type, 11 were any kind, and three were mixed type. The participants' clinical characteristics are described in table 2.

Table 3 shows the global MD FDT test in control and schizophrenia groups. Three patients were excluded from the FDT analysis due to poor performance on the test.

The patients with schizophrenia showed lower global mean sensitivity values (30.97 $\mathrm{dB} \pm 2.25$ ) in comparison with the control group mean (32.17 dB \pm 3.08$), p<0.009$. There was no difference in the delta sensitivity of hemispheres between patients and controls $(p<0.88)$ (Figure1).

There was a difference in sensitivity analysis of the fibers crossing the optic chiasm between patients and controls, with lower mean sensitivity in the schizophrenia group $(28.80 \mathrm{~dB})$ than in the control group (30.66 dB), $p=0.005$ (Figure 2 ).

The difference in sensitivity analysis of the fibers that did not cross the optic chiasm between patients and controls was higher, with lower mean sensitivity (27.61 dB) in the patient group versus (3026 dB) the control group ( $p=0.02)$.

There was no significant correlation between the global mean sensitivity values and the following independent variables: age, gender, length of time with diagnoses, antipsychotics used, presence or absence of positive and negative symptoms, and education level.

\section{DISCUSSION}

This study evaluated the visual processing deficits in schizophrenia by use of FDT. The advantages of FDT for early detection of magnocellular dysfunction are well documented. FDT shows good specificity (86-100\%) at high sensitivity (93\%), and has global indices that correlate highly with those of standard perimetry ${ }^{(26)}$. The finding in this study of a deficit in the magnocellular pathway in schizophrenia is consistent with results from some previous psychophysical studies, although they have also produced conflicting results ${ }^{(28)}$.

A number of psychophysical tests have been used to measure visual performance and to understand retinal ganglion cell deficits in schizophrenia ${ }^{(8,28)}$. Some studies using a visual backward masking paradigm, during which participants are asked to detect a stimulus
Table 1. Socio-demographic characteristics of patients with schizophrenia and healthy control participants

\begin{tabular}{lccc}
\hline & $\begin{array}{c}\text { Control } \\
(\mathbf{n = 3 4 )}\end{array}$ & $\begin{array}{c}\text { Schizophrenic } \\
(\mathbf{n = 3 1 )}\end{array}$ & p-value \\
\hline Gender (M/F) & $(8 / 26)$ & $(24 / 7)$ & 0.005 \\
VA (logMAR) - Mean (SD) & $0.01(0.04)$ & $0.04(0.06)$ & 0.100 \\
Age (years) - Mean (SD) & $32.10(13.7)$ & $37.80(12.30)$ & 0.081 \\
IOP (mmHg) - Mean (SD) & $12.16(2.44)$ & $14.13(2.99)$ & 0.005 \\
Refraction - Mean (SD) & $-0.33(1.41)$ & $-0.21(2.81)$ & 0.835 \\
\hline
\end{tabular}

$\mathrm{M}=$ male; $\mathrm{F}=$ female; $\mathrm{SD}=$ standard deviation; $\mathrm{IOP}=$ intraocular pressure; $\mathrm{VA}=$ visual acuity; Refraction= espheric equivalent.

Table 2. Clinical characteristics of the schizophrenic patients

\begin{tabular}{lccc}
\hline Patients $(\mathbf{n}=\mathbf{3 4})$ & Mean & SD & Range \\
\hline Disease duration (years) & 14.32 & 10.71 & $1-53$ \\
Age of onset (years) & 22.76 & 8.79 & $12-40$ \\
PANSS-N & 19.76 & 5.85 & $7-34$ \\
PANSS-P & 18.38 & 7.25 & $9-34$ \\
GAF & 43.94 & 11.05 & $20-65$ \\
CPZ (mg/d) & 367.50 & 242.56 & $50-1175$ \\
\hline
\end{tabular}

$\mathrm{SD}=$ standard deviation; $\mathrm{PANSS}-\mathrm{N}=$ negative PANSS score; PANSS-P= positive PANSS score; $\mathrm{GAF}=\mathrm{Global}$ Assessment of Functioning scale score; $\mathrm{CPZ}=$ chlorpromazine equivalent (mg/day).

Table 3. FDT results of global mean retinal sensitivity (FDT-MD) of schizophrenic patients and healthy control

\begin{tabular}{lccc}
\hline & $\begin{array}{c}\text { Schizophrenic } \\
\mathbf{n = 3 1}\end{array}$ & $\begin{array}{c}\text { Control } \\
\mathbf{n}=\mathbf{3 4}\end{array}$ & $\mathbf{p}$-value \\
\hline $\begin{array}{l}\text { FDT-MD (dB) } \\
\text { Mean (SD) }\end{array}$ & $30.97(2.25)$ & $32.17(3.08)$ & $\mathrm{p}<0.009$ \\
$\begin{array}{l}\text { FDT-MD (dB) } \\
\text { Crossing fibers }\end{array}$ & $28.80(5.02)$ & $30.66(2.48)$ & $\mathrm{P}=0.005$ \\
$\begin{array}{l}\text { FDT-MD (dB) } \\
\text { N-crossing fibers }\end{array}$ & $27.61(5.49)$ & $30.26(2.83)$ & $\mathrm{P}=0.002$ \\
Delta MD & $28.58(6.38)$ & $30.43(2.66)$ & $\mathrm{P}<0.88$ \\
\hline
\end{tabular}

FDT-MD = global mean sensitivity values; crossing fibers= fibers that cross the optic chiasm; $\mathrm{n}$-crossing fibers= fibers that do not cross the optic chiasm; Delta $\mathrm{MD}=$ delta sensitivity of hemispheres.

immediately followed by a mask, increased the possibility that the mask, which is processed by an overactive magnocellular pathway, may influence the lower performances on target detections ${ }^{(18,29)}$.

Studies using luminance contrast sensitivity measurements showed more pronounced differences. Schwartz et al. ${ }^{(15)}$ found selective contrast sensitivity impairments for temporally modulated low frequency gratings, which stimulate magnocellular neurons. Kéri et al. ${ }^{(30)}$ observed intact contrast sensitivity for magnocellular pathway stimuli.

A limitation of this study is that there has not been extensive testing of its psychophysical properties. Furthermore, the impact of training requires better investigation and test-retest reliability should be measured, especially in patients with cognitive impairments ${ }^{(31)}$.

New evidence from functional magnetic resonance imaging supports the hypothesis that schizophrenia is associated with impaired functioning of the magnocellular pathway and that these deficits 


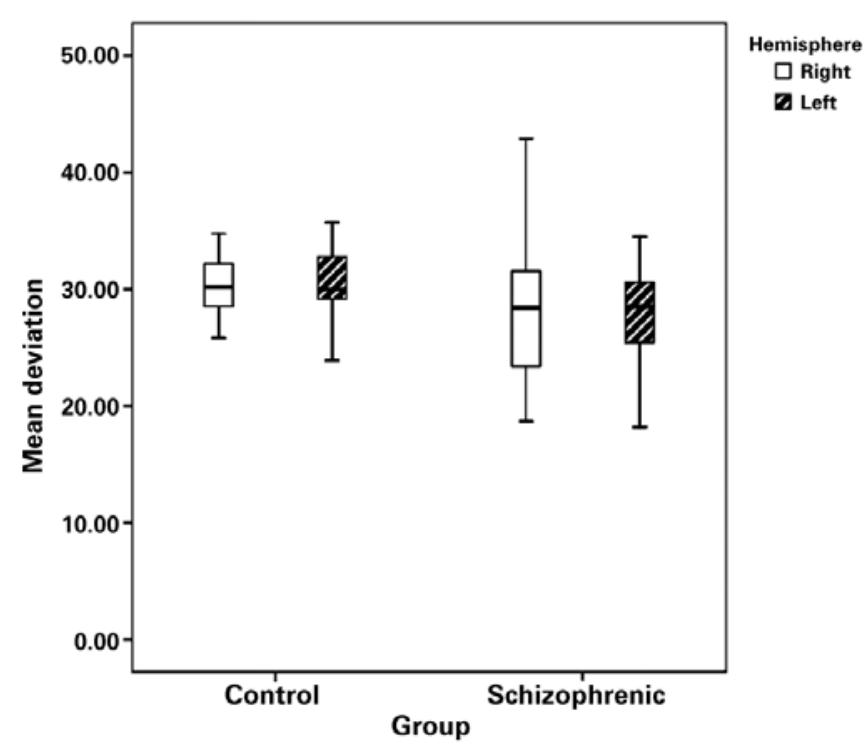

Figure 1. FDT-MD: global mean sensitivity values (in $\mathrm{dB}$ ); right and left hemispheres; presented as box-plots.

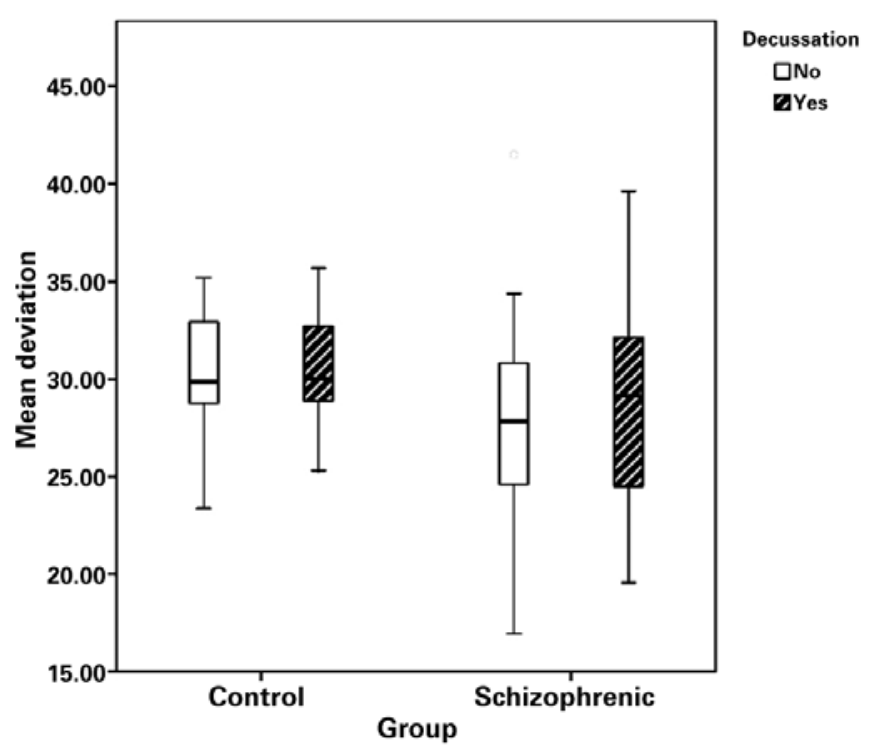

Figure 2.FDT-MD: global mean sensitivity values (in dB); crossing fibers (Decussation Yes) and n-crossing fibers (Decussation No); presented as box-plots.

may contribute to high-order cognitive deficits(32). Based on previous available data, it was hypothesized that a negative correlation would be found such that patients with the highest level of negative symptoms would show the greatest deficit in the magnocellular pathway ${ }^{(33)}$. In general, the results of the contrast sensitivity and masking studies suggest that visual processing is more intact in groups with predominantly positive symptoms and good premorbid history. In our sample, there was no correlation between length of time with the disease and age of onset.

In this study all patients were using antipsychotic drugs or other psychotropic agents for at least 6 months, and the medication effect cannot be excluded. Dopamine is present in the retina and there is evidence that a hypo-dopaminergic state could affect contrast sensitivity and color perception ${ }^{(34)}$. However, previous studies have shown no significant correlations between the antipsychotic dose and deficits in the magnocellular pathway ${ }^{(32,33)}$. In contrast, Braff and Saccuzzo ${ }^{(35)}$ found that medications reduced the backward masking deficit. In our sample, there was no correlation between FDT response and chlorpromazine-equivalent doses.

There is some evidence in literature that supports a right hemisphere advantage for processing global information, and left hemisphere preference for local information ${ }^{(36)}$. In our study, there was no difference in the delta sensitivity of hemispheres between patients and controls. However, Braus et al. ${ }^{(37)}$ used functional magnetic resonance imaging and found a hypoactivation in the magnocellular pathway, particularly in the right hemisphere of schizophrenic patients, but found no evidence of abnormal functioning in the area of the parvocellular pathway.

It was possible to verify the difference in sensitivity analysis of the fibers that do not cross the optic chiasm between patients and controls because of the particularities of ganglion cell anatomy ${ }^{(38)}$. The ganglion cells of the right and left eye visual receptive fields reflect half of the visual field in the opposite hemisphere. The crossing of fibers occurs in the retinal optic chiasm, where medial fibers cross the chiasm to join sides with the temporal fibers. In other words, the temporal retina ipsilateral hemispheric projection displays in the same side, while the nasal retina contralateral hemispheric projection displays in the opposite side. Because of this distribution of fibers, each outer half of the visual field is represented in the opposite cerebral hemisphere ${ }^{(38)}$

To the best of our knowledge, this is the first time in the literature that analyses of sensitivity between fibers that cross and do not cross the chiasm have been performed. The evidence presented here, for a lower sensitivity in fibers that do not cross the optic chiasm, is consistent with most current etiological hypotheses for schizophrenia involving genetic factors and anatomical processes (e.g., dysmyelination) $)^{(3,39)}$.

Our study showed significant decreased sensitivity responses in the optic radiations, which was consistent with the results from Butler et al. using diffusion tensor imaging to examine white matter integrity in schizophrenia ${ }^{(40)}$. The present findings suggest that there are differences between global sensitivity and fiber sensitivity measured by FDT, and may contribute to a significant body of research to assess early-stage visual processing deficits for patients with schizophrenia.

\section{REFERENCES}

1. Blomqvist AG, Léger PT, Hoch JS. The cost of schizophrenia: lessons from an international comparison. J Ment Health Policy Econ. 2006;9(4):177-83.

2. American Psychiatric Association. Diagnostic and statistical manual of mental disorders. DSM-IV. 4th edition. Washington (DC): American Psychiatry Association; 1994.

3. Pantelis C, Yücel M, Wood SJ, Velakoulis D, Sun D, Berger G, et al. Structural brain imaging evidence for multiple pathological processes at different stages of brain development in schizophrenia. Schizophr Bull. 2005;31(3):672-96.

4. Murray RM, Lewis SW. Is schizophrenia a neurodevelopmental disorder? Brit Med J (Clin Res Ed). 1987:295(6600):681-2.

5. Brenner CA, Krishnan GP, Vohs JL, Ahn WY, Hetrick WP, Morzorati SL, et al. Steady state responses: electrophysiological assessment of sensory function in schizophrenia. Schizophr Bull. 2009;35(6):1065-77.

6. Green MF, Nuechterlein KH. Backward masking performance as an indicator of vulnerability to schizophrenia. Acta Psychiatr Scand Suppl. 1999;395:34-40.

7. Kéri S, Benedek G. Visual contrast sensitivity alterations in inferred magnocellular pathways and anomalous perceptual experiences in people at high-risk for psychosis. Vis Neurosci. 2007:24(2):183-9.

8. Bedwell JS, Brown JM, Miller LS. The magnocellular visual system and schizophrenia: what can the color red tell us? Schizophr Res. 2003;63(3):273-84.

9. Butler PD, Abeles IY, Weiskopf NG, Tambini A, Jalbrzikowski M, Legatt ME, et al. Sensory contributions to impaired emotion processing in schizophrenia. Schizophr Bull. 2009; 35(6):1095-107.

10. Butler PD, Silverstein SM, Dakin SC. Visual perception and its impairment in schizophrenia. Biol Psychiatry. 2008;64(1):40-7. 
11. Kantrowitz JT, Butler PD, Schecter I, Silipo G, Javitt DC. Seeing the world dimly: the impact of early visual deficits on visual experience in schizophrenia. Schizophr Bull. 2009;35(6):1085-94.

12. Schwartz BD, Mallott DB, Winstead DK. Preattentive deficit in temporal processing by chronic schizophrenics. Biol Psychiatry. 1988;23(7):664-9.

13. Williams LE, Must A, Avery S, Woolard A, Woodward ND, Cohen NJ, et al. Eye-movement behavior reveals relational memory impairment in schizophrenia. Biol Psychiatry. 2010;68(7):617-24

14. Merigan WH, Maunsell JH. How parallel are the primate visual pathways? Annu Rev Neurosci. 1993;16:369-402.

15. Schwartz BD, McGinn T, Winstead DK. Disordered spatiotemporal processing in schizophrenics. Biol Psychiatry. 1987;22(6):688-98.

16. Schwartz BD, Maron BA, Evans WJ, Winstead DK. Smooth pursuit tracking deficits of patients with schizophrenia at specific within-sine wave bins. Neuropsychiatry Neuropsychol Behav Neurol. 1999;12(4):221-9.

17. Delord S, Ducato MG, Pins D, Devinck F, Thomas P, Boucart M, et al. Psychophysical assessment of magno- and parvocellular function in schizophrenia. Vis Neurosci. 2006;23(3-4):645-50.

18. Green MF, Nuechterlein KH, Breitmeyer B. Backward masking performance in unaffected siblings of schizophrenic patients. Evidence for a vulnerability indicator. Arch Gen Psychiatry. 1997;54(5):465-72. Erratum in Arch Gen Psychiatry 1997;54(9):846.

19. Noh J, Kim JH, Hong KS, Kim N, Nam HJ, Lee D, et al. Factor structure of the neurocognitive tests: an application of the confirmative factor analysis in stabilized schizophrenia patients. J Korean Med Sci. 2010;25(2):276-82.

20. Shapley R, Reid RC, Kaplan E. Receptive fields of $P$ and $M$ cells in the monkey retina and their photoreceptor inputs. Neurosci Res Suppl. 1991;15:S199-211.

21. Linvigstone MS, Hubel DH. Psychophysical evidence for separate channels for the perception of form, color, movement, and depth. J Neurosci. 1987;7(11):3416-68.

22. Williams JB, Spitzer RL, First MB, Gibbon M. Structured clinical interview for DSM-IV axis I disorders. Washington (DC): American Psychiatric Press; 1997.

23. Harding TW, Arango MV, Baltazar J, Climent CE, Ibrahim HH, Ladrido-Ignacio L, et al. Mental disorders in primary health care: a study of their frequency and diagnosis in four developing countries. Psychol Med. 1980;10(2):231-41.

24. Andreasen NC, Olsen S. Negative v positive schizophrenia. Definition and validation. Arch Gen Psychiatry. 1982;39(7):789-94.

25. Maddess T, Hemmi JM, James AC. Evidence for spatial aliasing effects in the Y-like cells of the magnocellular visual pathway. Vision Res.1998;38(12):1843-59.

26. Maddess T, James AC, Goldberg I, Wine S, Dobinson J. A spatial frequency-doubling illusion-based pattern electroretinogram for glaucoma. Invest Ophthalmol Vis Sci. 2000;41(12):3818-26.

27. Liang KY, Zeger SL. Longitudinal data analysis using generalized linear models. Biometrika. 1986;73(1):13-22

28. Skottun BC, Skoyles JR. On identifying magnocellular and parvocellular responses on the basis of contrast-response functions. Schizophr Bull. 2011;37(1):23-6.

29. Skottun BC, Skoyles JR. A few remarks on attention and magnocellular deficits in schizophrenia. Neurosci Biobehav Rev. 2008;32(1):118-22.

30. Kéri S, Antal A, Szekeres G, Benedek G, Janka Z. Visual information processing in patients with schizophrenia: evidence for the impairment of central mechanisms. Neurosci Lett. 2000;293(1):69-71.

31. Green MF, Butler PD, Chen Y, Geyer MA, Silverstein S, Wynn JK, et al. Perception measurement in clinical trials of schizophrenia: promising paradigms from CNTRICS. Schizophr Bull. 2009;35(1):163-81. Review.

32. Martínez A, Hillyard SA, Dias EC, Hagler DJ Jr, Butler PD, Guilfoyle DN, et al. Magnocellular pathway impairment in schizophrenia: evidence from functional magnetic resonance imaging. J Neurosci. 2008;28(30):7492-500. Erratum in J Neurosci. 2008; 28(37):9319.

33. Butler PD, Harkavy-Friedman JM, Amador XF, Gorman JM. Backward masking in schizophrenia: relationship to medication status, neuropsychological functioning, and dopamine metabolism. Biol Psychiatry. 1996;40(4):295-8.

34. Djamgoz MB, Hankins MW, Hirano J, Archer SN. Neurobiology of retinal dopamine in relation to degenerative states of the tissue. Vision Res. 1997;37(24):3509-29.

35. Braff DL, Saccuzzo DP. Effect of antipsychotic medication on speed of information processing in schizophrenic patients. Am J Psychiatry. 1982;139(9):1127-30.

36. Evans MA, Shedden JM, Hevenor SJ, Hahn MC. The effect of variability of unattended information on global and local processing: evidence for lateralization at early stages of processing. Neuropsychologia. 2000;38(3):225-39.

37. Braus DF, Weber-Fahr W, Tost H, Ruf M, Henn FA. Sensory information processing in neuroleptic-naive first-episode schizophrenic patients: a functional magnetic resonance imaging study. Arch Gen Psychiatry. 2002;59(8):696-701.

38. Tootell RB, Switkes E, Silverman MS, Hamilton SL. Functional anatomy of macaque striate cortex. II. Retinotopic organization. J Neurosci. 1988;8(5):1531-68.

39. Davis KL, Stewart DG, Friedman Jl, Buchsbaum M, Harvey PD, Hof PR, et al. White matter changes in schizophrenia: evidence for myelin-related dysfunction. Arch Gen Psychiatry. 2003;60(5):443-56. Review.

40. Butler PD, Hoptman MJ, Nierenberg J, Foxe JJ, Javitt DC, Lim KO. Visual white matter integrity in schizophrenia. Am J Psychiatry. 2006;163(11):2011-3. 